\title{
PENGARUH MOTIVASI DAN KECERDASAN EMOSI TERHADAP HASIL BELAJAR GEOGRAFI SISWA
}

\author{
${ }^{1}$ Nur Syahadani Putri, ${ }^{2}$ Mega Iswari, ${ }^{3}$ Riska Ahmad \\ ${ }^{1}$ Universitas Putra Indonesia "YPTK" Padang \\ ${ }^{2,3}$ Universitas Negeri Padang \\ nur.syahadani.putri@gmail.com.
}

\begin{abstract}
This research is motivated by the low achievement motivation and emotional intelligence of students. Achievement motivation and emotional intelligence are factors suspected to affect student Geography learning outcomes. This study aims to: (1) describe the achievement motivation, (2) describe the emotional intelligence, (3) describe Geography student learning outcomes, (4) the effect of achievement motivation on Geography student learning outcomes, (5) the effect of emotional intelligence on Geography student learning outcomes, (6) the effect of achievement motivation and emotional intelligence together on Geography student learning outcomes. This study used a descriptive quantitative method. The study population was a high school student 1 Nan Sabaris Pauh Kamba Pariaman XI class academic year 2014/2015 which amounted to 136 people, a sample of 102 people, which is selected by proportional random sampling technique. The instrument used was a scale for achievement motivation and scale for emotional intelligence. Analyzed with descriptive statistics, simple regression and multiple regression. The research findings show that (1) the achievement motivation of students in general are in the middle category, (2) students emotional intelligence in general are at a low category, (3) Geography student learning outcomes at a low category, (4) there is effect of the achievement motivation with Geography student learning outcomes, (5) there is effect of emotional intelligence with Geography student learning outcomes, (6) there is effect of between achievement motivation, emotional intelligence with Geography student learning outcomes. Implications of the research results serve as input to create a program of guidance and counseling services that can improve achievement motivation, emotional intelligence and Geography student learning outcomes.
\end{abstract}

Keywords: Achievement Motivation, Emotional Intelligence, Geography Student Learning Outcome

Abstrak: Penelitian ini dilatarbelakangi oleh rendahnya motivasi berprestasi dan kecerdasan
emosional siswa. Motivasi berprestasi dan kecerdasan emosional merupakan faktor yang
diduga dapat mempengaruhi hasil belajar Geografi siswa. Penelitian ini bertujuan untuk: (1)
mendeskripsikan motivasi berprestasi, (2) mendeskripsikan kecerdasan emosional, (3)
mendeskripsikan hasil belajar mahasiswa Geografi, (4) mengetahui pengaruh motivasi
berprestasi terhadap hasil belajar mahasiswa Geografi, (5) mengetahui pengaruh motivasi
berprestasi terhadap hasil belajar mahasiswa Geografi. Kecerdasan emosional terhadap hasil
belajar siswa geografi, (6) pengaruh motivasi berprestasi dan kecerdasan emosional secara
bersama-sama terhadap hasil belajar siswa geografi. Penelitian ini menggunakan metode
kuantitatif deskriptif. Populasi penelitian adalah siswa SMA Negeri 1 Nan Sabaris Pauh
Kamba Pariaman kelas XI tahun pelajaran 2014/2015 yang berjumlah 136 orang, sampel
sebanyak 102 orang, yang dipilih dengan teknik proporsional random sampling. Instrumen
yang digunakan adalah skala motivasi berprestasi dan skala kecerdasan emosional. Dianalisa
dengan statistik deskriptif, regresi sederhana dan regresi berganda. Hasil penelitian
menunjukkan bahwa (1) motivasi berprestasi siswa secara umum berada pada kategori sedang,
(2) kecerdasan emosional siswa secara umum berada pada kategori rendah, (3) hasil belajar
geografi siswa pada kategori rendah, (4) kecerdasan emosional siswa secara umum berada pada
kategori rendah, (3) hasil belajar geografi siswa pada kategori rendah, (4) ) terdapat pengaruh
motivasi berprestasi dengan hasil belajar siswa geografi, (5) ada pengaruh kecerdasan
emosional dengan hasil belajar siswa geografi, (6) ada pengaruh antara motivasi berprestasi,
kecerdasan emosional dengan hasil belajar siswa geografi. Implikasi dari hasil penelitian 
dijadikan sebagai bahan masukan untuk membuat program layanan bimbingan dan konseling yang dapat meningkatkan motivasi berprestasi, kecerdasan emosional dan hasil belajar geografi siswa.

Kata Kunci: Motivasi Berprestasi, Kecerdasan Emosional, Hasil Belajar Mahasiswa Geografi

\section{PENDAHULUAN}

Pendidikan merupakan kebutuhan (need) yang sangat penting dalam kehidupan manusia, karena dengan pendidikan manusia dapat mengembangkan potensi dirinya melalui proses belajar. Sesuai Undang - undang Republik Indonesia Nomor 20 tahun 2003 Bab 1 Pasal 1 tentang Sistem Pendidikan Nasional yaitu: "Pendidikan adalah usaha sadar dan terencana untuk mewujudkan suasana belajar dan proses pembelajaran agar peserta didik secara aktif mengembangkan potensi dirinya untuk memiliki kekuatan spiritual keagamaan, pengendalian diri, kepribadian, kecerdasan, akhlak mulia, serta keterampilan yang diperlukan dirinya, masyarakat, bangsa dan negara".

Sekolah sebagai lembaga formal yang mempunyai tujuan mulia melalui perwujudan suasana belajar yang kondusif untuk mengembangkan potensi diri siswa dalam mewujudkan tujuan pendidikan nasional. Hal ini dipertegas dalam Undang - undang Republik Indonesia Nomor 20 tahun 2003 Bab 2 Pasal 3 tentang Sistem Pendidikan Nasional yaitu: "Pendidikan nasional berfungsi mengembangkan kemampuan dan membentuk watak serta peradaban bangsa yang bermartabat dalam rangka mencerdaskan kehidupan bangsa, bertujuan untuk berkembangnya potensi peserta didik agar menjadi Marusia yang beriman dan bertakwa kepada Tuhan Yang Maha Esa, berakhlak mulia, sehat, berilmu, cakap, kreatif, mandiri, dan menjadi warga negara yang demokratis serta bertanggung jawab".

Tinggi rendahnya hasil belajar yang diperoleh siswa berkaitan dengan faktor-faktor yang dapat mempengaruhi hasil belajar itu sendiri, baik faktor yang berasal dari dalam (internal) maupun faktor yang berasal dari luar (eksternal). Daud (2012:244) berpendapat penyebab rendahnya hasil belajar siswa SMA sekarang ini sudah jelas tidak terlepas dari faktor umum. Pertama, yaitu faktor dari dalam diri siswa itu sendiri yang lazim disebut sebagai faktor internal. Faktor ini banyak didominasi oleh kondisi psikologis beserta segenap potensi siswa dalam bentuk kecerdasan, termasuk kecerdasan intelektual yang meliputi berbagai kemampuan, seperti penalaran, kemampuan berpikir abstrak, dan kemampuan verbal. Demikian juga faktor-faktor psikologis lainnya seperti motivasi berprestasi dan kecerdasan emosi yang meliputi ketabahan, keterampilan bergaul, empati, kesabaran, kesungguhan, keuletan serta ketangguhan. Motivasi berprestasi bertumpu pada tanggung jawab pribadi, standar keunggulan, kreatif dan inovatif, melakukan kegiatan dengan sebaikbaiknya, konsisten dalam mencapai cita-cita, sedangkan kecerdasan emosi bertumpu pada hubungan antara perasaan, watak, dan naluri moral yang mencakup pengendalian diri, semangat dan ketekunan, kemampuan menyesuaikan diri, kemampuan memecahkan masalah pribadi, mengendalikan amarah serta 
kemampuan untuk memotivasi diri sendiri.

Sehubungan dengan hasil belajar muncul beberapa fenomena yang memprihatinkan, seperti rendahnyamotivasi berprestasi dan kecerdasan emosi siwa dalam mencapai hasil belajar yang sesuai dengan kriteria ketuntasan minimum (KKM) yang telah ditentukan oleh pihak sekolah. Hal ini terlihat dari data ujian tengah semester siswa kelas XI semester II yang penulis dapatkan di SMA Negeri 1 Nan Sabaris tahun ajaran 2014/2015. Data yang penulis temukan di SMA Negeri 1 Nan Sabaris masih banyak terdapat siswa yang memperoleh hasil belajar mata pelajaran Geografi di bawah standar Kriteria Ketuntasan Minimum (KKM) yaitu 78. Hal ini dapat dilihat pada tabel di bawah ini:

Tabel 1. Jumlah Siswa yang Memiliki Nilai di Bawah Kriteria Ketuntasan Minimal pada Mata Pelajaran Geografi

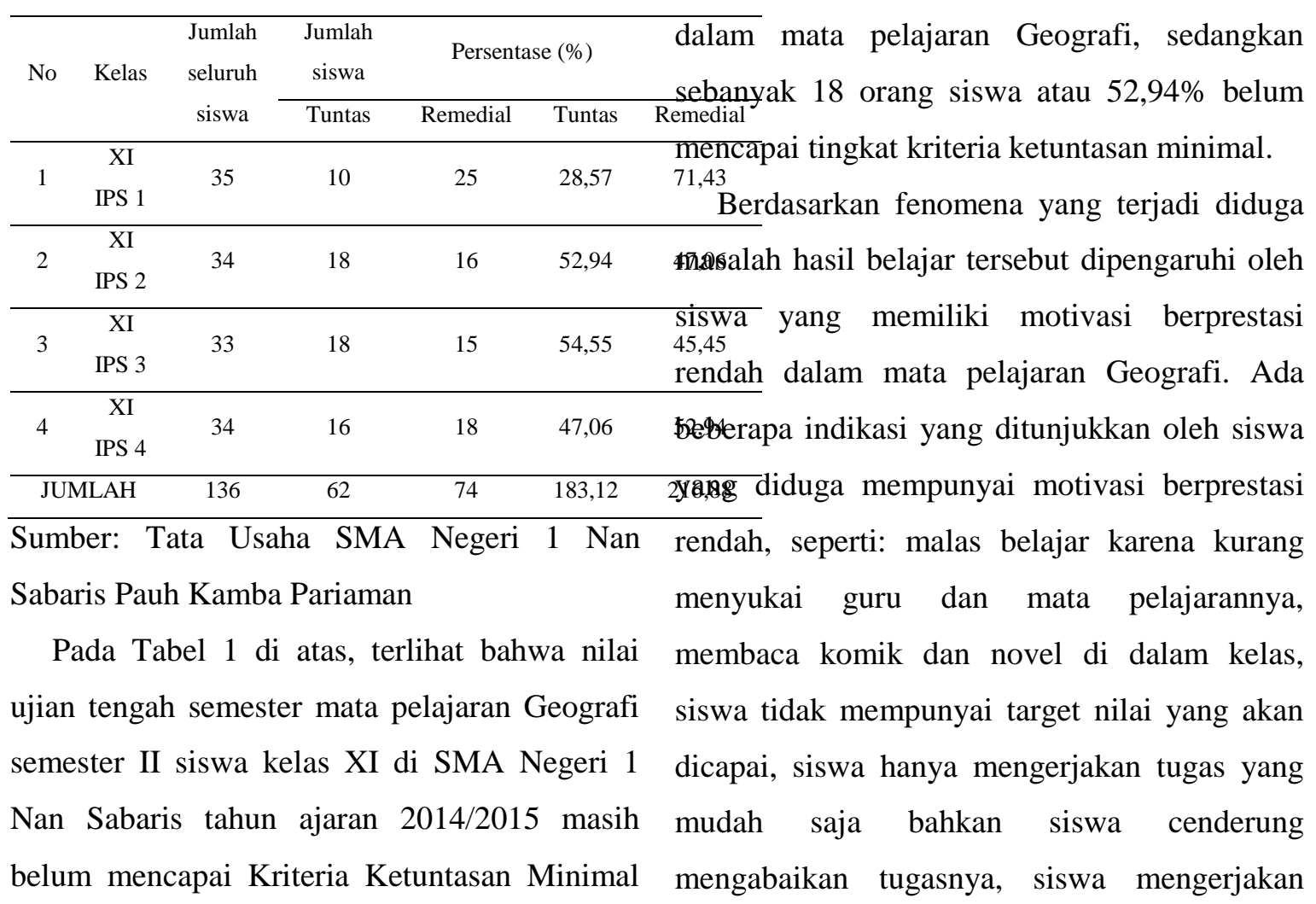

kelas XI IPS 1 terdapat 10 orang siswa atau $28,57 \%$ yang mencapai tingkat kriteria ketuntasan minimal dalam mata pelajaran Geografi, sedangkan 25 orang siswa atau $71,43 \%$ belum mencapai tingkat kriteria ketuntasan minimal. Begitu juga dengan kelas XI IPS 2 sebanyak 18 orang siswa atau 52,94\% yang mencapai tingkat kriteria ketuntasan minimal dalam mata pelajaran Geografi, sedangkan 16 orang siswa atau $47,06 \%$ belum mencapai tingkat kriteria ketuntasan minimal. Pada kelas XI IPS 3 sebanyak 18 orang siswa atau $54,55 \%$ yang mencapai tingkat kriteria ketuntasan minimal dalam mata pelajaran Geografi, sedangkan 15 orang siswa atau $45,45 \%$ belum mencapai tingkat kriteria ketuntasan minimal. Pada kelas XI IPS 4 sebanyak 16 orang siswa atau $47,06 \%$ yang mencapai tingkat kriteria ketuntasan minimal

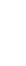

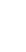

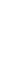


pekerjaan rumah di sekolah, mengobrol dengan teman pada saat guru menerangkan pelajaran, mencoret-coret buku yang tidak ada kaitannya dengan mata pelajaran Geografi. Hal tersebut menjelaskan motivasi berprestasi siswa masih menjadi masalah yang nyata dalam proses pembelajaran di sekolah. Selanjutnya, ditemukan pula beberapa indikasi yang ditunjukkan oleh siswa yang diduga memiliki kecerdasan emosi yang rendah, seperti: kurang berempati pada teman yang sedang mengalami permasalahan, jarang bertegur sapa baik pada guru maupun teman, tidak dapat mengendalikan emosi pada saat sedih, marah, bahagia, tidak mampu memecahkan masalah secara kolektifmurung serta tidak mampu memotivasi diri sendiri.

\section{METODE}

Penelitian ini menggunakan metode kuantitatif jenis deskriptif. Populasi penelitian adalah siswa kelas XI jurusan IPS SMAN 1 Nan Sabaris Pauh Kamba Pariaman Kabupaten Padang Pariaman yang berjumlah 136 orang, sampel berjumlah 102 orang dipilih dengan teknik Proportional Random Sampling. Instrumen yang digunakan adalah motivasi berprestasi dan kecerdasan emosi dengan model skala likert. Uji validitas instrumen penelitian menggunakan Product Moment Correlation dengan taraf signifikansi 0,05 . Uji reliabel terhadap instumen motivasi berprestasi siswa memiliki nilai Alfa Cronbach 0,916 dan kecerdasan emosi siswa memiliki nilai Alpha Cronbach sebesar 0,896. Data dianalisis dengan statistik deskriptif regresi sederhana dan regresi berganda. Analisis data dibantu dengan menggunakan program SPSS versi 20.00.

\section{HASIL}

A. Deskripsi Data

1. Motivasi Berprestasi

Tabel 2. Deskripsi Motivasi Berprestasi Berdasarkan Sub Variabel

\begin{tabular}{|c|c|c|c|c|c|c|c|c|c|}
\hline \multirow[b]{2}{*}{$\begin{array}{l}\text { Vari } \\
\text { abel }\end{array}$} & \multirow[b]{2}{*}{$\begin{array}{c}\text { Sub } \\
\text { variabel }\end{array}$} & \multicolumn{7}{|c|}{ Skor } & \multirow{2}{*}{$\begin{array}{l}\mathbf{K} \\
\mathbf{e} \\
\mathbf{t}\end{array}$} \\
\hline & & Ideal & $\max$ & Min & Total & Rata-rata & $\begin{array}{c}\% \\
\text { Rata- } \\
\text { rata }\end{array}$ & SD & \\
\hline \multirow{3}{*}{$\begin{array}{l}\text { Moti } \\
\text { vasi } \\
\text { Berp } \\
\text { resta } \\
\text { si }\end{array}$} & $\begin{array}{l}\text { Standar } \\
\text { Keunggulan } \\
\text { Tugas } \\
\text { (14) }\end{array}$ & 45 & 36 & 22 & 2871 & 28,1 & 62,5 & 3,09 & c \\
\hline & $\begin{array}{l}\text { Standar } \\
\text { Keunggulan } \\
\text { Diri } \\
(8) \\
\end{array}$ & 40 & 34 & 10 & 2333 & 23,1 & 57,1 & 5,1 & c \\
\hline & $\begin{array}{l}\text { Standar } \\
\text { Keunggulan } \\
\text { Siswa Lain } \\
\text { (3) } \\
\end{array}$ & 40 & 37 & 11 & 2300 & 23 & 56,3 & 5,8 & C \\
\hline \multicolumn{2}{|c|}{ Keseluruhan (25) } & 125 & 88 & 52 & 7504 & 73,6 & 58,85 & 7,06 & $\mathrm{C}$ \\
\hline
\end{tabular}

Berdasarkan Tabel 2 terlihat bahwa secara keseluruhan motivasi berprestasi siswa di sekolah berada pada kategori cukup (C), skor tertinggi sebesar 88 dari skor ideal 125, skor terendah adalah 52, skor total sebesar 7504, rata-rata skor 73,56 dengan persentase sebesar $58,85 \%$.

Secara rinci dari analisis data tampak bahwa skor tertinggi rata-rata motivasi berprestasi siswa terletak pada sub variabel standar keunggulan tugas dengan rata-rata sebesar 28,1 dan berada pada kategori cukup (C), kemudian skor rata-rata terendah terdapat pada sub variabel standar keunggulan siswa lain dengan rata-rata sebesar 23 dan berada pada kategori cukup (C). 
Putri- Pengaruh Motivasi Dan 129

2. Kecerdasan Emosi

\begin{tabular}{|c|c|c|c|c|c|c|c|c|}
\hline $\begin{array}{c}\text { Keseluruhan } \\
(30)\end{array}$ & 150 & 89 & 53 & 7302 & 71,5 & 47,7 & 7,9 & $\mathbf{R}$ \\
\hline
\end{tabular}

Tabel 3. Deskripsi Kecerdasan Emosi Berdasarkan Sub Variabel

Berdasarkan Tabel 3 terlihat bahwa

\begin{tabular}{|c|c|c|c|c|c|c|c|c|c|}
\hline \multirow[b]{2}{*}{ Variabel } & \multirow[b]{2}{*}{$\begin{array}{c}\text { Sub } \\
\text { Variabel }\end{array}$} & \multicolumn{7}{|c|}{ Skor } & \multirow{2}{*}{$\begin{array}{l}\mathrm{K} \\
\mathrm{e} \\
\mathrm{t}\end{array}$} \\
\hline & & Ideal & Max & Min & Total & $\begin{array}{l}\text { Rata } \\
\text {-rata }\end{array}$ & $\begin{array}{c}\% \\
\text { rata } \\
- \\
\text { rata }\end{array}$ & Sd & \\
\hline \multirow{5}{*}{$\begin{array}{c}\text { Kecerdasan } \\
\text { Emosi }\end{array}$} & $\begin{array}{c}\text { Mengenali } \\
\text { Emosi Diri } \\
(6)\end{array}$ & 30 & 23 & 11 & 1778 & 17,4 & 58,1 & 2,3 & C \\
\hline & $\begin{array}{l}\text { Mengelola } \\
\text { Emosi (6) }\end{array}$ & 30 & 25 & 6 & 1667 & 16,3 & 54,4 & 4,5 & C \\
\hline & $\begin{array}{c}\text { Memotivasi } \\
\text { Diri Sendiri } \\
(6)\end{array}$ & 30 & 25 & 6 & 1417 & 13,8 & 46,3 & 4,4 & $\mathbf{R}$ \\
\hline & $\begin{array}{c}\text { Mengenali } \\
\text { Emosi } \\
\text { Orang Lain } \\
\text { (6) } \\
\end{array}$ & 30 & 22 & 6 & 1320 & 12,9 & 43,1 & 4,7 & $\mathbf{R}$ \\
\hline & $\begin{array}{l}\text { Membina } \\
\text { Hubungan } \\
(6)\end{array}$ & 30 & 19 & 6 & 1120 & 10,9 & 36,6 & 3,4 & $\mathbf{R}$ \\
\hline
\end{tabular}

secara keseluruhan kecerdasan emosi siswa di sekolah berada pada kategori rendah (R), skor tertinggi sebesar 89 dari skor ideal 150, skor terendah adalah 53, skor total sebesar 7302, rata-rata skor 71,5 dengan persentase sebesar $47,7 \%$.

Secara rinci dari analisis data

kecerdasan emosi siswa terletak pada sub variabel mengenali emosi diri dengan rata-rata sebesar 17,4 dan berada pada kategori cukup (C), kemudian skor rata-rata terendah terdapat pada sub variabel membina hubungan dengan ratarata sebesar 10,9 dan berada pada kategori rendah (R).

3. Hasil Belajar

Tabel 4. Deskripsi Data Hasil Belajar Geografi (Y)

\begin{tabular}{cccc} 
Interval Skor & Kategori & Frekuensi & Persentase (\%) \\
\hline$\geq 89$ & $\begin{array}{c}\text { Sangat } \\
\text { Tinggi (ST) }\end{array}$ & 6 & 5,6 \\
\hline 79 s.d 88 & Tinggi (T) & 25 & 24,6 \\
\hline 72 s.d 78 & Cukup (C) & 23 & 22,7 \\
\hline 65 s.d 71 & Rendah (R) & 44 & 43,5 \\
\hline$\leq 64$ & $\begin{array}{c}\text { Sangat } \\
\text { Rendah (SR) }\end{array}$ & 4 & 3,6
\end{tabular}

Berdasarkan Tabel 4 terlihat bahwa dari keseluruhan sampel yang berjumlah 102 orang siswa, sebanyak 43,5\% hasil belajar mata pelajaran Geografi siswa berada pada kategori rendah $(\mathrm{R})$ dengan jumlah frekuensinya 44 siswa. Selanjutnya disusul pada kategori tinggi (T) dengan jumlah frekuensinya 25 siswa atau dapat dipersentasekan pada 24,6\%, kemudian pada kategori cukup (C) tampak bahwa skor tertinggi rata-rata diperoleh jumlah frekuensinya 23 siswa yang dapat dipersentase dengan nilai $22,7 \%$, selanjutnya pada kategori sangat tinggi (ST) diperoleh frekuensinya 6 siswa yang dipersentasekan dengan nilai $5,6 \%$, sedangkan untuk kategori sangat rendah (SR) diperoleh frekuensinya 4 siswa yang dipersentasekan dengan nilai $3,6 \%$.

\section{PEMBAHASAN}

Hasil pengujian data yang telah diuraikan diatas, maka didapatkan bahwa terdapat hubungan motivasi berprestasi dan kecerdasan emosi dengan hasil belajar geografi siswa. Pada bagian berikut ini akan dijelaskan variabel yang dikaji dalam penelitian ini.

1. Motivasi Berprestasi.

$$
\text { Hasil analisis deskriptif }
$$
menunjukkan motivasi berprestasi siswa berada pada kategori cukup (C) dengan rata-rata skor sebesar 73,56 dapat dipersentasekan sebesar $58,85 \%$. Secara rinci dari analisis data tampak bahwa skor tertinggi rata-rata motivasi berprestasi siswa terletak pada sub 
variabel standar keunggulan tugas dengan rata-rata sebesar 28,1 dan berada pada kategori cukup (C), kemudian skor rata-rata terendah terdapat pada sub variabel standar keunggulan siswa lain dengan rata-rata sebesar 23 dan berada pada kategori cukup (C).

Siswa yang memiliki motivasi berpretasi akan melakukan upaya untuk menghindari kegagalan, ketika siswa itu mengalami kegagalan maka siswa tersebut tidak larut dalam kekecewaannya justru hal tersebut akan dijadikan cambuk untuk lebih baik dari sebelumnya. Sedangkan seseorang yang memperoleh keberhasilan karena dia takut gagal, ketika mengalami kegagalan maka dia akan terlarut dalam kekecewaan karena dalam dirinya tertanam rasa takut, malu, takut dihina, bahkan takut mendapat hukuman. Jadi usaha tersebut tidak secara tulus datang dari dalam individu tersebut.

Menurut McClelland

karakteristik individu yang mempunyai motivasi berprestasi antara lain sebagai berikut:

1) Memiliki tanggung jawab pribadi

Seseorang yang memiliki motivasi berprestasi yang tinggi merasa bertanggung jawab atas tugas yang dikerjakannya dan tidak akan meninggalkan tugas tersebut sebelum berhasil menyelesaikannya. Sebaliknya, seseorang yang memiliki motivasi berprestasi rendah, cenderung akan menyalahkan hal-hal diluar dirinya sebagai penyebab kegagalannya seperti: tugas yang dikerjakan terlalu sulit atau terlalu banyak.

2) Risiko pemilihan tugas

Seseorang yang memiliki motivasi berprestasi tinggi akan memilih tugas dengan taraf kesulitan sedang. Walaupun tugas itu sulit baginya tetapi individu tersebut tetap berusaha menyelesaikan tugas dan berani mengambil risiko bila mengalami kegagalan. Sebaliknya, seseorang yang memiliki motivasi berprestasi rendah cenderung memilih tugas yang mudah saja, karena yakin akan mampu menyelesaikannya dan bila mengalami kegagalan, maka individu tersebut tidak akan menyalahkan tugas tersebut.

3) Memperhatikan umpan balik

Seseorang yang mempunyai motivasi berprestasi tinggi menyukai umpan balik. Umpan balik yang didapatkannya dijadikan sebagai pengalaman untuk tidak mengulangi kesalahan-kesalahan yang dilakukan pada tugas sebelumnya. Sedangkan, seseorang yang memiliki motivasi berprestasi rendah, cenderung akan mengulangi kesalahan-kesalahan yang sama dalam menyelesaikan tugas yang mendatang.

4) Inovatif dan kreatif 
Seseorang yang memiliki motivasi berprestasi yang tinggi cenderung tidak menyukai pekerjaan rutin, lebih suka mengerjakan sesuatu yang berbeda dari sebelumnya, lebih suka mencari informasi untuk menemukan cara-cara yang lebih baik dalam mengerjakan segala sesuatu, dan selalu bergerak dari sesuatu yang telah dilakukan untuk mencari hal-hal lain.

2. Kecerdasan Emosi.

Hasil analisis deskriptif menunjukkan bahwa motivasi berprestasi siswa pada kategori rendah (R), skor tertinggi sebesar 89 dari skor ideal 150 , skor terendah adalah 53, skor total sebesar 7302 , rata-rata skor 71.5 dengan persentase sebesar $47.7 \%$. Setiap individu berbeda dari segi inteligensinya, karena berbeda segi inteligensinya maka individu yang satu dengan yang lain tidak sama kemampuannya dalam memecahkan suatu persolan yang dihadapi. Ahmadi (2009:89) menyatakan pada orang yang inteligensinya tinggi akan lebih cepat dan lebih tepat dalam menghadapi masalah - masalah baru bila dibandingkan dengan orang yang kurang inteligensinya.

\section{Salovey (dalam Goleman,} 1995:45) menempatkan kecerdasan pribadi Gardner dalam definisi dasar tentang kecerdasan emosi yang dicetuskannya, seraya memperluas kemampuan ini menjadi lima wilayah utama yaitu: (a) mengenali emosi diri, (b) mengelola emosi, (c) memotivasi diri sendiri, (d) mengenali emosi orang lain, (e) membina hubungan sosial.

3. Hasil Belajar.

Hasil analisis deskriptif menunjukkan bahwa $43 \%$ siswa hasil belajar mata pelajaran Geografi siswa berada pada kategori rendah (R) dengan jumlah frekuensinya 44 siswa. Hasil belajar merupakan tolak ukur dari keberhasilan siswa dalam proses pembelajaran yang diadakan. Hasil belajar dapat dipengaruhi oleh beberapa faktor, Menurut Slameto (2010:54-72) bahwa hasil belajar dipengaruhi oleh dua faktor: 1) Faktor intern (faktor yang berasal dari diri sendiri) yang terbagi atas 3 faktor yaitu; faktor jasmaniah yang meliputi kesehatan dan cacat tubuh, faktor psikologis yang terdiri dari inteligensi, perhatian, minat, bakat, motif, kematangan,dan kesiapan serta faktor kelelahan. 2) Faktor ekstern (faktor yang berasal dari luar diri sendiri) terdiri dari 3 faktor yaitu; faktor keluarga yang terdiri dari cara orangtua mendidik, relasi antar anggota keluarga, suasana rumah, keadaan ekonomi keluarga, pengertian orangtua dan latar belakang kebudayaan. Faktor sekolah yang terdiri dari metode mengajar, relasi guru dengan siswa, relasi siswa dengan siswa lainnya, disiplin sekolah, waktu sekolah, dan tugas rumah. Faktor masyarakat yang terdiri dari kegiatan siswa dalam 
masyarakat dan teman bergaul. Faktor psikologis sangat berperan mempengaruhi hasil belajar siswa dan merupakan faktor yang berasal dari dalam diri siswa (inteligensi, minat, motivasi, perhatian, kematangan dan kesiapan).

4. Pengaruh Motivasi Berprestasi Terhadap Hasil Belajar Geografi Siswa.

Berdasarkan hasil analisis data, pengaruh motivasi berprestasi terhadap hasil belajar Geografi siswa adalah: $\mathrm{R}^{2}=$ 0,276 yang berarti terdapat pengaruh motivasi berprestasi terhadap hasil belajar Geografi siswa sebesar $27,6 \%$. Sedangkan $72,4 \%$ dipengaruhi oleh variabel lain yang belum diteliti pada penelitian ini, sehingga dapat ditarik kesimpulan bahwa semakin baik motivasi berprestasi siswa maka cenderung memperoleh hasil belajar Geografi yang baik dan begitu pula sebaliknya, jika motivasi berprestasi siswa tidak baik maka hasil belajar Geografinya juga cenderung tidak baik. Menurut Gellerman (1984:150) siswa yang memiliki dorongan berpestasi yang kuat akan memperoleh nilai yang lebih baik dari pada siswa yang dorongan berprestasinya lebih rendah. Semakin kuat dorongan untuk berprestasi, maka semakin besarlah kemungkinan bagi siswa untuk menuntut dirinya berusaha lebih keras lagi.

5. Pengaruh Kecerdasan Emosi Terhadap Hasil Belajar Geografi Siswa.
Berdasarkan analisis data, pengaruh kecerdasan emosi terhadap hasil belajar Geografi siswa adalah: $R^{2}=$ 0,259 yang berarti terdapat pengaruh kecerdasan emosi terhadap hasil belajar Geografi siswa sebesar 25,9\%. Sedangkan $74,1 \%$ dipengaruhi oleh variabel lain yang belum diteliti pada penelitian ini, sehingga dapat diambil kesimpulan bahwa jika kecerdasan emosi tinggi maka hasil belajar akan menjadi baik pula, dan begitu sebaliknya, jika kecerdasan emosi rendah maka hasil belajar cenderung rendah. Siswa yang memiliki kecerdasan emosi yangbaik menampakkan minat yang besar dan perhatian yang penuh terhadap belajar dan tugas, tanpa mengenal perasaan bosan, serta dapat mengendalikan emosi, menimbulkan rasa empati yang tinggi dan dapat membina hubungan sosial yang baik dengan sesama begitu pula sebaliknya pada siswa yang memiliki kecerdasan emosi yang kurang baik, mereka akan memperlihatkan sikap keengganan, tertutup, cenderung arogan, cepat bosan dan berusaha menghindar dari kegiatan belajar.

Hal tersebut sesuai dengan pendapat Goleman menyatakan bahwa peran penting kecerdasan emosi bagi siswa yang pada akhirnya dapat meningkatkan hasil belajar siswa adalah sebagai berikut: "Kecerdasan emosi memperbaiki dan meningkatkan nilai prestasi akademik 
siswa. Penemuan ini bukanlah penemuan terpisah, ini terjadi berulang kali dalam pengamatan yang sejenis. Dimasa- masa ketika ada begitu banyak anak yang tak mampu menangani kemurungan mereka, untuk mendengarkan atau memusatkan perhatian, untuk mengendalikan dorongan hati, untuk merasa bertanggungjawab terhadap pekerjaan mereka, atau menaruh perhatian pada pelajaran, apa saja yang bisa mendukung keterampilan ini akan membantu pendidikan mereka".

Berdasarkan pendapat di atas, dapat dipahami bahwa kecerdasan emosi berhubungan dengan hasil belajar siswa. Siswa yang cerdas secara emosi akan dapat mengatur dan mengendalikan suasan hati dan emosinya sehingga ketika sedang dihadang oleh berbagai permasalahan, maka siswa tersebut akan lebih mampu memfokuskan konsentrasinya dalam belajar dibandingkan siswa yang tidak cerdas secara emosi.

6. Pengaruh Motivasi Berprestasi dan Kecerdasan Emosi Secara bersama-sama Terhadap Hasil Belajar Geografi Siswa

Berdasarkan hasil analisis data yang dilakukan memperlihatkan bahwa terdapat pengaruh motivasi berprestasi dan kecerdasan emosi terhadap hasil belajar Geografi siswa $\left(R^{2} 0,307\right)$. Hal ini berarti hasil belajar Geografi siswa dipengaruhi oleh motivasi berprestasi dan kecerdasan emosi secara bersama-sama sebesar $\quad 30,7 \%$ dan $\quad 69,3 \%$ berkemungkinan dipengaruhi oleh variabel lain yang belum diteliti pada penelitian ini.

Berdasarkan data di atas dapat disimpulkan bahwa semakin baik motivasi berprestasi siswa dan semakin tinggi kecerdasan emosi maka semakin baik pula hasil belajar siswa, dan begitu sebaliknya jika motivasi berprestasi siswa kurang baik dan kecerdasan emosi rendah maka hasil belajar siswa akan kurang baik pula.

7. Implikasi Layanan Bimbingan dan Konseling terhadap Motivasi Berprestasi dan Kecerdasan Emosi dengan Hasil Belajar Geografi Siswa.

Berdasarkan temuan penelitian, maka ada beberapa implikasi layanan bimbingan dan konseling terhadap motivasi berprestasi dan kecerdasan emosi dengan hasil belajar geografi siswa, yaitu: (1) layanan informasi, (2) layanan konseling perorangan, layanan bimbingan kelompok.

\section{SIMPULAN}

Berdasarkan hasil temuan yang diperoleh dalam penelitian ini, maka dapat disimpulkan sebagai berikut.

1. Motivasi berprestasi siswa berada pada kategori cukup.

2. Kecerdasan emosi siswa berada pada kategori rendah.

3. Hasil belajar Geografi siswa rata - rata berada pada kategori rendah, karena rata- 
rata nilai siswa tidak mencapai Kriteria

Ketuntasan Minimal (KKM) yang ditetapkan oleh sekolah yaitu: 78 .

4. Terdapat pengaruh antara motivasi berprestasi siswa dengan hasil belajar Geografi siswa. Hubungan motivasi berprestasi terhadap hasil belajar Geografi adalah:. Nilai $\mathrm{r}^{2}$ sebesar 0.276 menunjukkan bahwa besarnya pengaruh motivasi berprestasi dengan hasil belajar Geografi siswa sebesar $27.6 \%$.

5. Terdapat pengaruh antara kecerdasan emosi siswa dengan hasil belajar Geografi siswa. Pengaruh kecerdasan emosi terhadap hasil belajar Geografi adalah: Nilai $\mathrm{r}^{2}$ sebesar 0.259 menunjukkan bahwa besarnya pengaruh kecerdasan emosi dengan hasil belajar Geografi siswa sebesar $25.9 \%$.

6. Terdapat pengaruh antara motivasi berprestasi dan kecerdasan emosi siswa secara bersama-sama terhadap hasil belajar Geografi siswa. Dapat disimpulkan, bahwa koefisien regresi ganda yang diperoleh dalam penelitian ini signifikan. Hasil analisis regresi $\mathrm{r}^{2}=0.307$, dapat dipahami bahwa terdapat pengaruh antara motivasi berprestasi dan kecerdasan emosi dengan hasil belajar Geografi.

\section{DAFTAR RUJUKAN}

Ahmadi, A. 2009. Psikologi Umum. Jakarta:RinekaCipta.

Daud, F. 2012. "Pengaruh Kecerdasan Emosional dan Motivasi Belajar terhadap Hasil Belajar Biologi Siswa SMA 3 Negeri Kota Palopo.Jurnal Pendidikan dan Pembelajaran", 19 (2).
Gellerman, W. S. 1961. Motivasi dan Produktivitas.Terjemahan oleh Soepomo S. Wardoyo. 1984. Jakarta: Djaya Pirusa.

Goleman, D. 1995. Emotional Intelligence: Why it Can Matter More Than IQ. United State of America: Bantam Book.

Goleman, D. 1999. Working with Emotional Intelligence: Kecerdasan Emosi untuk Mencapai Puncak Prestasi.Terjemahan Alex Tri KantjoWidodo. Jakarta: Gramedia Pustaka Utama.

McClelland, D. C. 1987. Human Motivation. Glenview, IL: Scott Foresman..

Slameto. 2010. BelajardanFaktor-faktor yang Mempengaruhinya. Jakarta: RinekaCipta.

Undang-undang Republik Indonesia Nomor 20 tahun 2003 tentang Sistem Pendidikan Nasional. 2003. Jakarta: Sekretaris Negara Republik Indonesia. 